\title{
Entre chamas e labaredas: histórias de fogueiras de impressos em Florianópolis no século XX
}

\author{
Felipe Matos* \\ Maria Teresa Santos Cunha**
}

Resumo: O presente artigo relata três momentos de destruição de impressos através de sua queima pública, em Florianópolis, Santa Catarina, nos anos de 1917, 1950 e 1964, destacando-se a destruição de livros da Livraria Anita Garibaldi, que havia pertencido ao escritor Salim Miguel, em 1964, por evidenciar um ritual público, violento e persecutório, organizado por homens que decidiram eliminar toda a expressão de ideias contrárias aos seus interesses. As similaridades e disparidades dos três casos aqui registrados, documentados através de jornais, revistas e relatos memorialísticos, salientam o papel e o lugar do impresso nas sociedades contemporâneas, além de colocarem em evidência os chamados biblioclastas, com tais acontecimentos convergindo para se conhecer a intolerância reacionária presente na cultura de destruição de livros e nos embates entre o sectarismo e a liberdade intelectual em pleno século XX.

Palavras-chave: Queima de impressos. Salim Miguel. Livros proibidos. Liberdade intelectual.

"Doutor em História Cultural pela Universidade Federal de Santa Catarina (UFSC); Pesquisador da Scientia Consultoria Científica.

E-mail: felipematos@hotmail.com, https://orcid.org/0000-0001-5324-7101

"w" Doutora em Educação pela Universidade de São Paulo (USP). Professora Titular do Departamento de História da Universidade do Estado de Santa Catarina (UDESC) e docente dos PPG/Educação e PPG/ História da UDESC. Bolsista Produtividade em Pesquisa/CNPq. E-mail: mariatsc@gmail.com, https://orcid. org/0000-0001-6200-6713 
A fogueira em que são lançados os maus livros constitui a figura invertida da biblioteca encarregada de proteger e preservar o patrimônio textual. Dos autos-de-fé da Inquisição às obras queimadas pelos nazis, a pulsão de destruição obcecou por muito tempo os poderes opressores [...]. A força do escrito é de ter tornado tragicamente derrisória esta negra vontade (CHARTIER, 1998, p. 23).

Na vasta história da destruição de livros, nem sempre é fácil avaliar a razão que move os homens a aniquilarem os seus impressos. O escritor venezuelano Fernando Báez, em sua História Universal da Destruição dos Livros, constatou: "há 55 séculos se destroem livros, e mal se conhecem as razões” (BÁEZ, 2006, p. 21). Pode-se, no entanto, aferir que, grosso modo, os biblioclastas agem visando não apenas destruir objetos físicos, mas, sobretudo, o vínculo que tais objetos estabelecem com uma memória social, com a racionalidade que eles representam, com o patrimônio de ideias e de ideais que encerram em suas páginas e que, de alguma maneira, perturbam a ortodoxia de um sistema dominante e totalitário. A eliminação deliberada de impressos parece falar sobre indivíduos ou grupos de indivíduos interessados em manter, sem obstáculos, os dogmas de uma concepção de mundo uniforme e autossuficiente.

No intuito de salientar a importância de uma história da circulação dos impressos, suas práticas e usos sociais, este artigo relata três episódios de destruição de livros em Florianópolis, Santa Catarina, ocorridos em períodos e contextos distintos: em 1917, com a queima de livros da biblioteca de um clube germânico, em meio aos temores que emergiram com a Primeira Guerra Mundial; em 1950, quando no seio de uma tradicional escola católica da cidade seus alunos promoveram uma fogueira de revistas consideradas leituras perniciosas; e, por fim, mais detalhadamente, o caso ocorrido em 1964, quando a Livraria Anita Garibaldi foi invadida, saqueada e seus livros incinerados dias após o golpe civil-militar instaurado no país.

Como se verá a seguir, os biblioclastas, de modo geral, não são homens ignorantes ou uma turba inconsciente de seus ódios e de seus atos, mas atores sociais que vislumbram na destruição uma estratégia - violenta e persecutória - de preservação dos seus 
dogmas. Eles não são contra todo e qualquer livro, mas contra aqueles que vão de encontro aos seus próprios livros, que julgam eternos e irrefutáveis (BÁEZ, 2006, p. 24-27).

\section{Uma fogueira com ardor patriótico}

Análises que se tornaram referência sobre antigermanismo, como os estudos de Rene Gertz, demonstram que, no sul do Brasil, os estereótipos e preconceitos contra os descendentes germânicos surgiram ainda no século XIX, recrudescendo no imaginário popular nos períodos críticos entre as duas grandes guerras mundiais (GERTZ, 1998). É esse o caso de Santa Catarina, onde as tensões interétnicas entre alemães e brasileiros apontam para as disputas étnicas, políticas, culturais e religiosas, incentivadas por uma elite de procedência lusitana que elaborou o discurso do "perigo alemão", em que o país seria vítima de uma conspiração para se criar a Alemanha Antártida, alimentando em grupos nacionalistas um rancor contra os imigrantes germânicos (FALCÃO, 2000, p. 169).

A imigração alemã no Estado ocorreu dentro do ciclo de grandes emigrações europeias pós-guerras napoleônicas e o início da Primeira Guerra. Especificamente em Florianópolis, a presença desses imigrantes está intimamente relacionada com a fundação da primeira colônia alemã no Estado, São Pedro de Alcântara (1829). Famílias com destino à colônia resolveram permanecer em Desterro e São José, onde encontraram um núcleo populacional já estabelecido (KLUG, 1994, p. 26). Tais imigrantes desenvolveram mecanismos de defesa de sua germanidade através do associativismo, sendo que, no início do século XX, Florianópolis possuía entidades como a Associação do Cemitério da Comunidade Alemã, a Associação Escolar Alemã, a Associação da Frota Alemã, a Associação dos Atiradores, a Associação Ginástica Jahn, a Comunidade Evangélica Alemã, a Associação de Senhoras Alemãs, a Sociedade Beneficente Alemã, entre outras instituições (KLUG, 1994, p. 72).

A mais antiga sociedade de alemães em Florianópolis era o Club Germânia, fundado como um clube de canto em 1866, sob o nome de Euterpe e direção do músico e homeopata Guilherme 
Hautz. A agremiação passou a se chamar Germânia em 1871, após a guerra franco-prussiana, em homenagem à restauração do império alemão sob o comando de Guilherme I. Por meio de ações passadas entre os imigrantes da cidade, os associados construíram um edifício próprio na Rua Tenente Silveira, inaugurado em 16 de setembro de 1900. Nesse local foi instalada a biblioteca da instituição, que, em 1899, contava com 520 obras, representadas em 610 volumes (MATOS, 2008a).

Essa sede do Club Germânia foi atacada por populares em 28 de outubro de 1917, dois dias após o Brasil ter declarado guerra à Alemanha, durante a Primeira Guerra Mundial. Na ocasião, segundo a narrativa do jornal O Dia, de 30 de Outubro de 1917, um grupo de populares, que se reunia inicialmente na Praça XV de Novembro, organizou um "préstito patriótico" que circulou pelas ruas da cidade a fim de ouvir os discursos de figuras públicas locais, como o do então jovem advogado Nereu Ramos, filho do exgovernador Vidal Ramos e que viria a se tornar personagem central das campanhas de nacionalização das zonas coloniais nas décadas de 1930 e 1940, quando assumiu como Interventor do Estado. Os oradores foram intensamente aplaudidos e bem sucedidos na função de alertar a população para o estado de guerra, insuflando-os contra o "perigo alemão". Ao fim dos discursos, quando parte da população se dispersava, uma parcela dos presentes foi em direção à Livraria Central, fundada em 1910 pelos irmãos Entres, Alberto e Godofredo, de origem alemã. Como naquele momento a casa comercial não estava aberta, o grupo começou um apedrejamento do edifício, espatifando todas as nove vidraças do prédio. Os livros, no entanto, foram salvos da destruição, pois as portas resistiram à tentativa de arrombamento e os manifestantes tomaram o rumo do Club Germânia, distante duas quadras dali.

Nada dentro do clube foi poupado. A intenção dos manifestantes era atear fogo ao prédio, mas foram convencidos a desistirem dessa ideia sob o argumento de que possivelmente todas as demais casas do quarteirão poderiam pegar fogo, por se tratarem de construções coloniais muito próximas umas das outras. No entanto, todo o mobiliário e demais objetos encontrados no interior da agremiação, das cortinas ao piano, dos lustres às cerâmicas dos 
banheiros, foram jogados na rua em frente a casa, com a intenção de fazerem uma grande fogueira. $\mathrm{O}$ mesmo se deu com as centenas de livros da biblioteca, majoritariamente obras de autores alemães e em língua alemã, reunidas pelos associados desde o século XIX.

Durante todo o período de guerra que se seguiu, a tensão entre brasileiros e alemães e seus descendentes nunca foi totalmente dissipada, e os ataques a pessoas, residências e estabelecimentos comerciais associados aos alemães continuaram. Em 14 de julho de 1918, a Livraria Central foi novamente apedrejada após uma cerimônia cívica em que discursaram novamente nomes como Nereu Ramos. Além da Livraria Central, a livraria e tipografia Cysne, de Mathias Schonnenbeck, foi invadia em 21 de Maio de 1919, após a recusa do seu proprietário em imprimir um artigo a respeito de Guilherme II, Kaiser derrubado pela revolução alemã de 1918-1919 (Jornal República, 23/5/1919).

O patriotismo que alimentou o ardor dos manifestantes foi um tema candente na Primeira República, período em que se buscava garantir a irreversibilidade do novo regime e legitimar os novos atores sociais em suas disputas por poder. Os pronunciamentos e discursos em sacadas e janelas, tão comuns no período, emprestavam um caráter de espetáculo público às ações da República e contribuíam na fixação da construção da nova hierarquia social e política na capital catarinense (CHEREM, 2000, p. 88-98). A presença de Nereu Ramos nesses eventos públicos, discursando à multidão, demonstrava o antigermanismo alimentado pelas disputas políticas locais. Representante da oligarquia Ramos, Nereu, como fundador do jornal A Noite, em Florianópolis, usou as páginas do seu periódico para defender a causa dos países aliados e fazer campanha em favor da declaração de guerra do Brasil à Alemanha. Em 1916, Nereu não havia conseguido se reeleger deputado estadual, em parte pelos conflitos entre a sua família e Filipe Schmidt (CPDOC, 2016), governador que sucedeu seu pai no comando do Estado e primo-irmão de Lauro Müller, políticos de origem germânica que disputavam o poder nas entranhas do Partido Republicano. Essa dualidade e disputa de poder entre as elites de origem luso-brasileiras e teuto-brasileiras se tornou ainda mais explícita nas décadas seguintes, com a polarização política entre os Ramos, originários 
de Lages, representando os pecuaristas e extratores de erva mate do planalto catarinense, e os Konder Bornhausen, do Vale do Itajaí, mais atrelados às atividades comerciais e industriais.

A eclosão da Primeira Guerra Mundial agravou as desconfianças e reforçou os preconceitos contra os imigrantes e seus descendentes, dificultando a sua integração à sociedade local. Essas tensões foram novamente reacendidas quando do rompimento das relações diplomáticas do Brasil com a Alemanha e demais países do Eixo, em 22 de agosto de 1942, durante a Segunda Guerra Mundial. Sob o comando de Nereu Ramos, voltou a haver ainda mais fortemente, em todo o território estadual, uma explícita "suspeição/ demonização" dos alemães pela imprensa (FÁVERI, 2004, p. 43). Há diversos registros de alemães, em Santa Catarina, enterrando os seus livros, revistas e demais impressos em língua alemã (como demonstraram FAVERI, 2004; WERLE, 2015, por exemplo), com medo de serem denunciados e presos nos campos de concentração, além do acontecimento de novos ataques e boicotes aos comerciantes alemães, sendo que o livreiro Alberto Entres, da Livraria Central, chegou a ser preso sob a acusação de cantar a canção "Noite Feliz" em alemão durante uma noite de Natal (FÁVERI, 2004, p. 244-246).

\section{A fogueira das restrições religiosas}

O segundo relato de destruição de impressos na cidade data de 1950, trinta e três anos após o fogo consumir os livros da biblioteca do clube alemão. Uma nova fogueira foi acessa, desta vez sob os auspícios do Colégio Catarinense, tradicional instituição de ensino reservada às elites locais e comandada pelos padres jesuítas da Companhia de Jesus. Entre os anos de 1945 a 1950 circulou no colégio um pequeno jornal chamado $O$ Colegial: órgão dos alunos do Colégio Catarinense, que, entre outras questões relacionadas com o mundo escolar, publicava sugestões de leituras indicadas e autorizadas pela instituição aos seus alunos. O periódico foi pesquisado pela historiadora Márcia Regina dos Santos, que em seu trabalho de conclusão de curso (SANTOS, 2003) listou 222 títulos de livros citados pelo jornal, muitos deles acompanhados de uma 
resenha que visava à orientação dos sentidos das leituras, fazendo recomendações positivas ou restrições de obras e autores.

Através dessas indicações de leituras é possível perceber como as histórias em quadrinhos, um gênero específico de literatura que se tornava cada vez mais popular entre os jovens, passou a ser considerado particularmente pernicioso pelos padres. No Brasil, a igreja foi a primeira grande inimiga dos quadrinhos desde que Adolfo Aizen e Roberto Marinho revolucionaram o mercado dessas publicações na década de 1930. De início, a igreja importou da Itália a ideologia fascista difundida pelo Ministério Popular da Cultura de Benito Mussolini, o qual preconizava que tais obras promoviam uma "desnacionalização" entre os jovens, sobretudo os quadrinhos norte-americanos, acusados de imporem padrões e gostos estrangeiros às crianças, violando princípios cristãos, morais e éticos, além de incentivarem a delinquência infanto-juvenil (GONÇALO JR., 2004, p. 77-78).

A proliferação das histórias em quadrinhos no Brasil tornouse pauta dos mais variados espaços católicos de discussões, como nos encontros de bispos e nas pastorais. $\mathrm{O}$ padre carioca Arlindo Vieira se notabilizou por escrever, em periódicos católicos, artigos denunciando revistas como o clássico "Gibi”, do Grupo Globo, como exemplo de publicações prejudiciais aos estudos, incentivadores do "sexo solitário" e promotora da alienação cultural dos leitores (GONÇALO JR., 2004, p. 79-80). Segundo dados publicados pelo pesquisador Gonçalo Junior (2004, p. 121), estima-se que, em 1940, $75 \%$ dos jovens brasileiros que sabiam ler consumiam revistas juvenis, tornando a sua leitura um hábito consolidado no país, a despeito das campanhas que difundiam uma série de preconceitos morais e ideológicos. O mercado de impressos, em Florianópolis, não ficou indiferente, comercializando as revistas que permaneceram por muito tempo na memória de seus leitores. $\mathrm{O}$ escritor catarinense Adolfo Boos Jr., ex-aluno do Colégio Catarinense, comentou em entrevista que as histórias em quadrinhos foram uma de suas leituras de infância, um hábito que ele carregava consigo desde antes de se tornar aluno do colégio dos jesuítas, instituição com normas mais rígidas e que encampou dentro de seus muros a cruzada antiquadrinhos: 
Quando fui para o Grupo Escolar Lauro Müller fui pelo braço de uma tia que era professora, Emília Schmidt, que é nome de rua aqui em Coqueiros. Fui com uma recomendação da dona Mariazinha Gama, que foi minha primeira professora: “ó, escrever ele sabe tudo!”. Eu fui alfabetizado muito cedo. Eu li muito cedo, mas eu não lia em sala de aula. Estava chegando ao Brasil uma revista mensal em papel jornal chamada "Gibi”. Até hoje tem esse nome de gibi. Meu avô comprava para o filho mais moço dele, que era quatro ou cinco anos mais moço que eu... Ele também jogou no Avaí, o Artur. Quando ele acabava de ler, ele me dava a revista... Fui alfabetizado muito cedo, fui para o Grupo Escolar lendo. Só não lia em aula. Dali, minha tia foi para o Dias Velho e me levou com ela. Essa moleza acabou quando eu entrei no Colégio Catarinense, que eu comecei a ir para a porrada (MATOS, 2008b, p. 159).

O Colégio Catarinense, notável por sua rígida disciplina, desejava manter o controle sobre a formação intelectual de seus alunos orientando-os para uma "leitura sã". Em igual medida, as religiosas que dirigiam o Colégio Coração de Jesus, instituição secular para educação feminina em Florianópolis, também demonstravam preocupação com as leituras das alunas e recomendavam romances de orientação católica - a chamada Biblioteca das Moças - a elas, como forma de leitura sadia autorizada (CUNHA, 1999). O controle das leituras era constante, ainda que não se tenha conhecimento das religiosas haverem fomentado campanhas contra "leituras perniciosas" como as que culminaram numa fogueira de quase dois metros de altura composta por revistas em quadrinhos. A fogueira foi produzida por alunos do Colégio Catarinense e que viam a si mesmos como pertencentes a uma cruzada contra publicações impróprias, conforme registrou o jornal "O Colegial", de agosto de 1950:

\section{Queima de gibis}

Como resultado da campanha contra as leituras perniciosas, os cruzados juntaram uns duzentos Gibis e outras revistas semelhantes. A queima dessas publicações foi feita no dia 12/8, após a reunião. Para facilitar a queima, os cruzados 
desfizeram as revistas e amassaram as folhas, construindo uma fogueira de quase dois metros de altura. "Íbis”, o Capitão Marwel, o Super-Homem, e muitos outros "heróis", desta vez não conseguiram escapar das vermelhas labaredas que os conduziram a cinza (O Colegial, agosto/1950, no $\mathrm{n}^{5}$ /6 apud SANTOS, 2003, p. 41).

Nesse episódio de fogueira de revistas, os próprios alunos atuaram como censores de leituras que, na visão da formação pretendida pelo colégio, iriam ocasionar distorções em seu desenvolvimento educacional, merecendo, portanto, as chamas da fogueira. Além dos quadrinhos infanto-juvenis, cabe ressaltar ainda que, embora não fossem explicitamente queimados em praça pública, os chamados livros de bolso de Carlos Zéfiro, quadrinhos eróticos/pornográficos que circularam nos anos de 1950 e 1960, também mereceram reprimendas religiosas e foram considerados materiais passíveis de serem queimados pela Igreja Católica (CUNHA, 2010).

\section{A fogueira das perseguições políticas}

Por fim, o último caso aqui registrado envolve o arrombamento, furto, depredação e queima de livros da Livraria Anita Garibaldi, também conhecida como "Livraria do Salim", por ter sido fundada pelo escritor Salim Miguel (1924-2016) e por seu sócio, o advogado e produtor cultural Armando Carreirão (1925-2007). Não há muitos dados precisos sobre a história da livraria, mas sabese que ela iniciou como uma pequena banca de jornais e revistas, junto ao Café Rio Branco, um movimentado ponto de encontro no centro de Florianópolis. De propriedade de Euclides Pereira, mais conhecido como Quidoca, o Café Rio Branco, localizado na primeira quadra da Rua Felipe Schmidt, próximo à Praça XV de Novembro, foi um importante lócus de discussões políticas na década de 1940. Embora comumente associado aos seus frequentadores simpatizantes da UDN (União Democrática Nacional), o local recebia, democraticamente, clientes de todas as orientações políticas. A partir da segunda metade dos anos 40, o Rio Branco 
tornou-se também um dos pontos de encontro dos intelectuais do Círculo de Arte Moderna (Grupo Sul), que costumavam reunir-se em suas mesas para discutir os próximos números da revista Sul e as correspondências recebidas pela redação do periódico, além de conversar sobre as leituras feitas por cada uma, geralmente de livros adquiridos na Livraria Rosa, do livreiro João Teixeira da Rosa Jr., ele também um frequentador do Café e que tinha o hábito de passar de mesa em mesa comentando as novidades literárias recebidas por seu estabelecimento (MATOS, 2008b).

O Café Rio Branco se ofertava como um espaço em que parte da intelectualidade da cidade conseguia exercer sua criatividade, dando vazão às sensibilidades artísticas e políticas sacrificadas no horário de trabalho. De tanto frequentar o local, Salim Miguel e Armando Carreirão convenceram Quidoca a lhes deixar instalar, à esquerda de quem entrasse no Café, um balcão e uma prateleira de pau-marfim e pés palito, onde Salim, além de comercializar livros, jornais e revistas, passava horas a fazer indicações de leituras aos amigos. Assim, de forma modesta, foi fundada a Livraria Anita Garibaldi, como relembra o escritor Adolfo Boos Jr.:

Naquele balcão, com o laconismo habitual, [Salim] recomendou-me a leitura de Vidas Secas, sob sua orientação travei contato com William Faulkner, minhas primeiras recorrências literárias e, do mesmo jeito, vieram Charles Morgan, Theodore Dreiser, John Steinbeck, Dos Passos, Ehrenburg, Raimond Radiguet, Gogol e Tchecov, Osman Lins, Marques Rebelo, um nunca mais acabar de mestres deste nosso difícil, ingrato, mas sempre prazeroso ofício (CARDOZO, 2001, p. 30).

Por meio dos anúncios publicitários do estabelecimento publicados nas páginas da "Revista Sul", pode-se afirmar que a livraria funcionou no interior do Café Rio Branco ao menos entre os anos de 1953 até, possivelmente, o início de 1955, pois no $\mathrm{n}^{-} 25$ da revista, lançado em maio de 1955, aparece o primeiro anúncio da livraria tendo como novo endereço a Praça XV de Novembro, na quadra entre as ruas Felipe Schmidt e Conselheiro Mafra: 
Livraria Anita Garibaldi Ltda.

(Livros, jornais, revistas)

A melhor seleção de obras;

Aceita qualquer encomenda de livros nacionais ou estrangeiros;

Atende pelo reembolso postal.

Sempre as últimas novidades em livros e publicações nacionais e estrangeiras.

Caixa Postal, 358.

Agora em seu novo ponto e com suas novas e modernas instalações, à Praça 15 de Novembro, 27 (Revista Sul, no 25 , maio/1955, p. 96).

Nessa nova localização, as instalações mais amplas permitiram expandir o estoque de livros, especialmente com obras que dificilmente eram encontradas em outras livrarias da cidade. Eram, sobretudo, livros "de esquerda", alguns ligados ao Partido Comunista, obras importadas de editoras da Argentina, edições da Fondo de Cultura Económica do México, de editoras francesas e espanholas, edições de arte, clássicos da literatura nacional e estrangeira (MIGUEL; MALHEIROS, 2002, p. 60). O escritor Silveira de Souza, membro do Grupo Sul e frequentador da livraria, num relato memorialístico, oferece uma descrição física do estabelecimento:

O espaço poderia ser definido como um retângulo longo e estreito. Pouco mais de meia dúzia de passos nos levavam à parede do fundo. Uma única porta para entrada e saída. Havia o pequeno balcão quase rente a uma parede lateral, onde ficava sentado numa banqueta o único funcionário atendente da casa, José Furstenberg, o Pulga. Entretanto, talvez nunca antes ou depois em Florianópolis uma livraria conseguiu congregar diariamente tantos escritores, artistas, universitários, funcionários públicos, políticos e profissionais liberais, enfim, leitores de toda espécie, como aquele exíguo espaço, enquanto ele durou. Tornou-se um hábito, saía-se de casa para espairecer, para dar uma volta no centro da cidade e, quando a gente se dava conta, estava a conversar com alguém na 'livraria do Salim' (CARDOZO, 2001, p. 24). 
Entre chamas e labaredas: histórias de fogueiras de impressos...

Figura 1 - Interior da Livraria Anita Garibaldi.

Salim Miguel é o $2^{\underline{a}}$ da esquerda para a direita. Armando Carreirão é o $1^{\mathrm{a}}$ da direita para a esquerda.
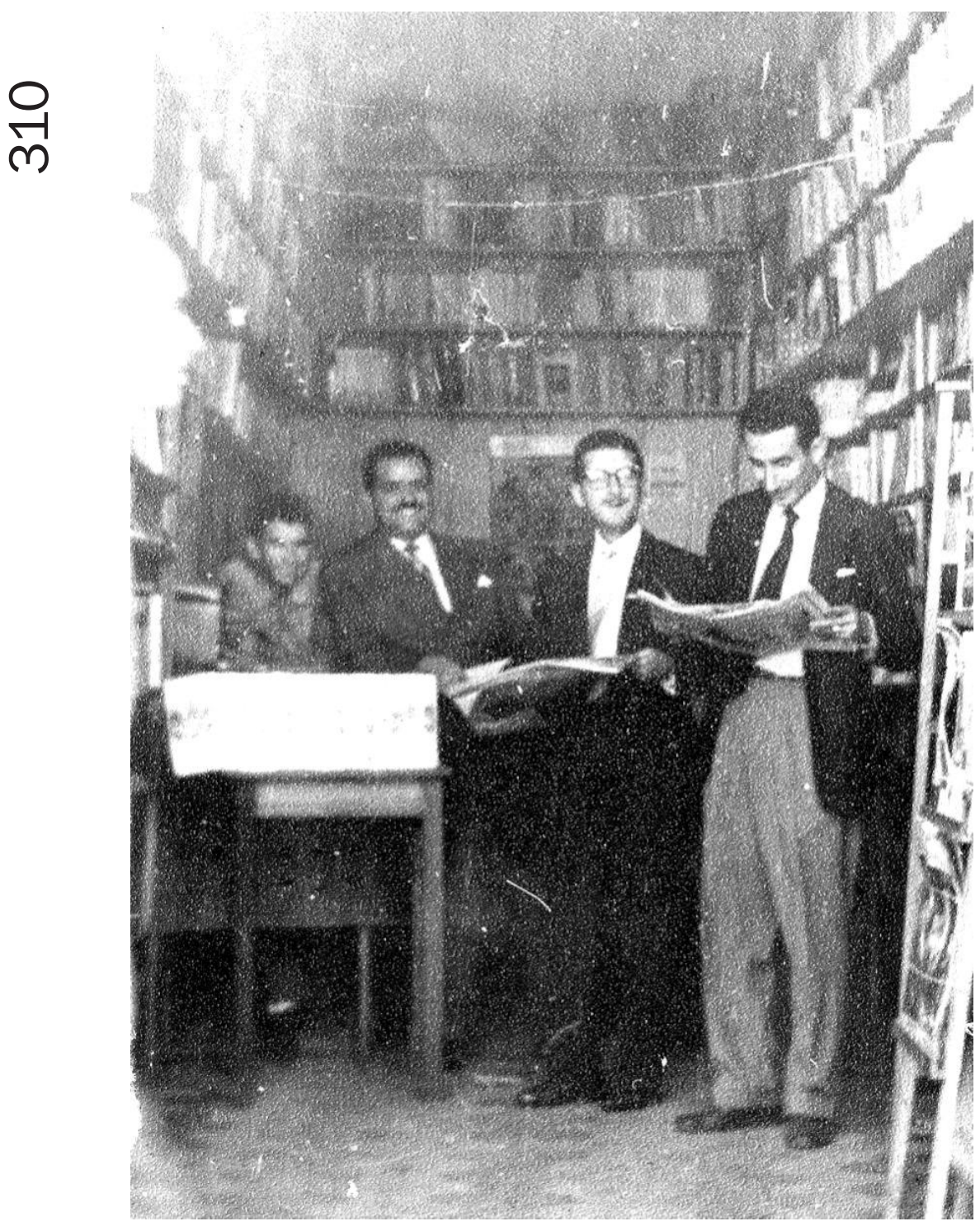

Fonte: Acervo de Salim Miguel e Eglê Malheiros.

Anos 90, Porto Alegre, v. 25, n. 48, p. 299-326, dez. 2018 
Embora tenha se tornado ponto de encontro de jornalistas, escritores e políticos, os donos da livraria, Salim Miguel e Armando Carreirão, chegaram à conclusão, em 1959, de que financeiramente o empreendimento não se mantinha. Era prática habitual dos livreiros facilitarem ao máximo as vendas, os livros recebiam grandes descontos e poderiam ser pagos em prestações a perder de vista. Mesmo com essas facilidades, a livraria vendia menos do que o necessário para a sua manutenção. Era comum que, ao receber alguma encomenda interessante, a livraria adquirisse dois exemplares, um para a venda ao cliente e outro para Salim, que, como sócio, não pagava pelos livros. Assim, por decisão de Armando Carreirão, os dois resolveram passar o ponto, que acabou sendo adquirido por um amigo em comum, Fernando Pereira Cristino, secretário-geral do Partido Comunista em Santa Catarina, mais conhecido pelo pseudônimo "Cláudio" (Diário Catarinense, 26/3/1996, encarte especial, p. 10).

Figura 2 - Livraria Anita Garibaldi nos anos 50.

Da esquerda para a direita: Silveira de Souza, Aníbal Nunes Pires, Salim Miguel, Murilo Pirajá, Emanuel Santos e Heleno Mendonça.

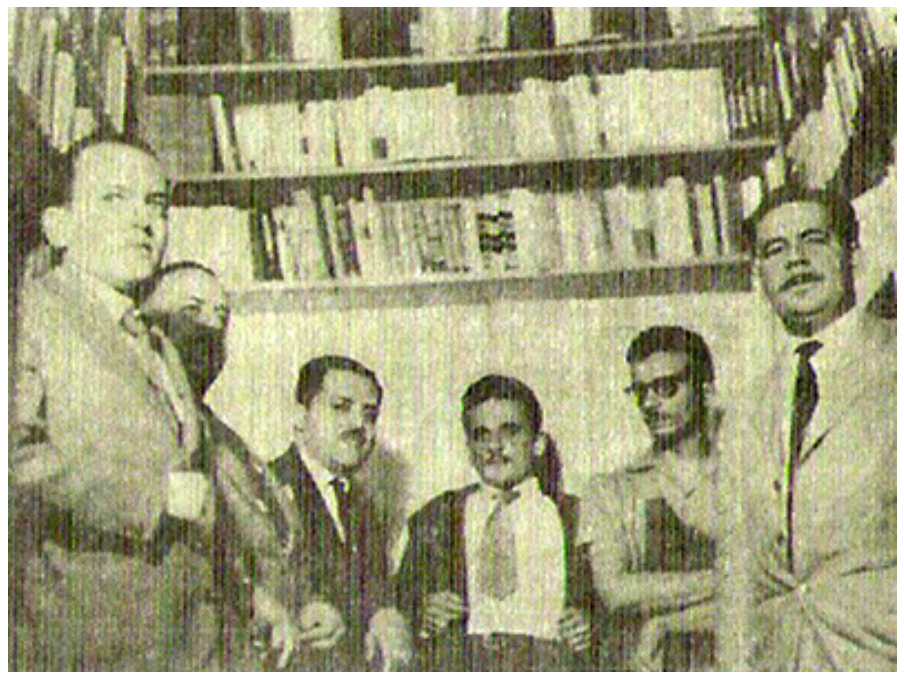

Fonte: Reprodução, Diário Catarinense, 26 mar. 1996, encarte especial, p. 10. 
Entre chamas e labaredas: histórias de fogueiras de impressos...

O historiador e jornalista Celso Martins entrevistou Fernando para o jornal "A Notícia", em matéria publicada em 18 de março de 2001, o que nos permite conhecer um pouco da vida dessa personagem importante para a história da livraria, por vezes ofuscada pela força da imagem de Salim Miguel, escritor de renome nacional. Nascido no Rio de Janeiro, em 11 de julho de 1924, Cristino foi enviado por Carlos Marighella e Diógenes de Arruda Câmara a Santa Catarina, em 1957, como interventor da direção estadual do PCB, com a missão de reorganizar a seção local do partido, devido a uma crise instaurada entre as direções estadual e municipal. Sua ligação com o Partido Comunista iniciou na adolescência, pela convivência com colegas de escola que tiveram os pais presos na revolta comunista de 1935, que buscou derrubar o governo de Getúlio Vargas através da ação da Aliança Nacional Libertadora (ANL), liderada por Luís Carlos Prestes. Em 1942, ajudou a estruturar um grupo de jovens, em Madureira (RJ), em apoio ao envio de Pracinhas brasileiros à Itália, para combater o nazi-fascismo. Em 1944, enquanto ganhava a vida como tecelão em fábricas cariocas, ingressou oficialmente no PCB. Em 1952, viu-se desempregado por participar de movimentos grevistas e acabou acolhido como funcionário da direção estadual do partido, permanecendo nessa situação até 1957, quando foi enviado para Florianópolis.

Na capital catarinense, utilizando o nome "Cláudio", mantinha-se como funcionário do partido e comerciante à frente da Livraria Anita Garibaldi. Ele residiu no Morro do Céu, numa casa alugada por dois antigos militantes comunistas, o marceneiro e carpinteiro João Verzola e o eletricista Manoel Alves Ribeiro, o Mimo. Enquanto morou em Santa Catarina, o militante ajudou a organizar conferências do partido e congressos sindicais, além de greves de operários das minas de carvão nas cidades catarinenses de Criciúma e Içara. Na noite de 31 de março de 1964, véspera do golpe civil-militar que tirou João Goulart da presidência da República, Cláudio estava na sede da União Catarinense dos Estudantes (UCE), situada na Rua Álvaro de Carvalho, discutindo com estudantes e militantes do PCB a tensa situação política do país. A direção do partido achou melhor escondê-lo, temendo que, confirmado o golpe, ele se tornasse um alvo fácil para a polícia. Após certa relutância, 
Cláudio foi se esconder na residência do desembargador José do Patrocínio Gallotti, na Avenida Trompowski, lá permanecendo até ser ajudado por amigos, entre eles Alcides Hermógenes Ferreira, a fugir para Curitiba e, de lá, para a sua terra natal. Na fuga, foi obrigado a deixar para trás a mulher e seus sete filhos, até reorganizar a vida e levá-los de volta ao Rio de Janeiro (A Notícia, 18 mar. 2001).

Cláudio permaneceu na militância do partido e, no ano de 1967, se tornou secretário do Comitê Central do PCB. Enquadrado na Lei de Segurança Nacional, acabou preso em 30 de maio de 1975 pelo DOI/CODI/I, no Rio de Janeiro, e transferido, em agosto daquele mesmo ano, para o DOI/CODI/II, em São Paulo, local em que foi barbaramente torturado. Quando entrevistado por Celso Martins, em 2001, aos 77 anos, ele ainda carregava consigo as sequelas da tortura, tendo sido obrigado a implantar próteses na bacia que o incapacitaram de se abaixar para colocar as meias ou mesmo calçar os próprios sapatos. Cláudio era, portanto, um membro ativo e muito visado do Partido Comunista, o que colaborou para colocar a Livraria Anita Garibaldi na mira das ações violentas da militância de inspiração católica e vezo conservador que a invadiu, depredou e fez uma fogueira com seus livros em plena Praça XV de Novembro, no dia 3 abril de 1964.

Apesar de a livraria pertencer a Cláudio desde 1959, o reduto continuou associado ao escritor Salim Miguel, tanto por ele ter sido um de seus fundadores quanto por sua presença constante no lugar. A Livraria Anita Garibaldi tornou-se uma referência icônica na cidade como lócus de sociabilidade da esquerda política. Ela foi estigmatizada como "reduto comunista", o que se tornara potencialmente perigoso no início dos anos 60, época em que recrudesceram os diversos elementos do imaginário anticomunista em parcelas da população, como atesta o depoimento do funcionário público Orival Prazeres, frequentador da livraria entre os anos de 1962 a 1963, quando era estudante universitário:

[...] era impossível deixar de vê-lo [Salim Miguel] se ali estivesse, sempre observando os livros, lendo ou em conversas com os amigos. Nunca lhe dirigi a palavra. Meu provincianismo e timidez impediam uma maior aproximação. Apenas 
adentrava, olhava um livro e outro (me seduziam as obras da Editora Zahar, sempre muito caras), lia as informações de capa e, assim, ia se estabelecendo minha relação com o mundo de Salim Miguel, um escritor com ideias socialistas, esposo da professora Eglê e amigo de outros meus ex-professores, Damiani e Martins, todos então rotulados de comunistas. A recordação que sempre me acompanhou é que a livraria de Salim Miguel envolvia um ambiente cercado de mistério, um local onde supostamente os comunistas se encontravam, o que, de certo modo, inibia uma aproximação mais aberta. Afinal, a cultura dominante considerava os comunistas como ateus sanguinários, agentes a serviço da Rússia e seus simpatizantes meros inocentes úteis aos interesses do regime soviético e da ditadura do proletariado (CARDOZO, 2001, p. 37-38).

O próprio Salim Miguel chegou a ficcionalizar a Livraria Anita Garibaldi num dos contos da obra $O$ sabor da fome, inicialmente publicado ao longo de uma reportagem do jornal Diário Catarinense, em 2005, e que posteriormente foi publicado em livro, pela Editora Record, em 2007:

Naquela época, Florianópolis era uma cidadezinha acomodada, mas não escapara à efervescência política, grupos das mais variadas tendências se digladiavam. [...] Ia me esquecendo da livraria Anita Garibaldi, que passei a frequentar mal cheguei à cidade: trazia recomendação expressa, era um reduto dos comunas, da esquerda intelectual, de políticos, estudantes, operários, lugarzinho acanhado no tamanho, mas fervilhante de agito. Tornei-me logo conhecido, eram na maioria ingênuos, de boa fé [...] (Diário Catarinense, suplemento Cultura, 2 abr. 2005, p. 14).

Quando o governo de João Goulart foi deposto pelo golpe civil-militar de 1964, Salim Miguel trabalhava como chefe do escritório da Agência Nacional em Florianópolis e na assessoria de imprensa do governador Celso Ramos (PSD). Logo no dia 2 de 
abril, enquanto tomava um café no Ponto Chic, Salim foi preso e conduzido para o Quartel do Comando Geral da Polícia Militar, na Rua Visconde de Ouro Preto, em frente à Praça Getúlio Vargas, lá permanecendo 48 dias junto a um grupo de 55 pessoas apontadas com subversivas ou relacionadas ao comunismo, acontecimento narrado pelo escritor no livro "Primeiro de Abril - Narrativas da cadeia”, lançado pela editora José Olympio em 1994. Ao contrário de sua esposa, a escritora e professora Eglê Malheiros, Salim não era membro do Partido Comunista. Ele era apenas um simpatizante das ideias de esquerda, mas se tornou um alvo previsível da militância conservadora por alguns motivos: os seus laços de amizade e convivência com militantes e intelectuais locais; por seu envolvimento com a Livraria Anita Garibaldi, adquirida por um notório comunista; e, ainda, por sua polêmica atuação como um dos líderes do Grupo Sul, o primeiro movimento abertamente modernista da cidade, que nas décadas de 1940 e 1950 entrou em conflito contra intelectuais conservadores, associados à Academia Catarinense de Letras (MATOS, 2014), sendo, a partir de então, todos eles taxados indiscriminadamente de comunistas pelas ideias de vanguarda que defendiam.

Por volta das 18 horas do dia três de abril de 1964, enquanto Salim estava na cadeia e Cláudio preparava a sua fuga da cidade, populares arrombaram as portas da Livraria Anita Garibaldi, que se encontrava fechada desde o dia $1^{\underline{a}}$ daquele mês. Segundo a narrativa elaborada pelo jornal $A$ Gazeta, de cinco de abril, os agressores retiraram da livraria "todos os livros de literatura marxista" e "puseram fogo em plena via pública sob os aplausos da multidão que ocorreu ao local". O jornal, solidário ao golpe e porta-voz da UDN, frisou que "o povo florianopolitano deu provas sobejas de sua fibra democrática, extinguindo um foco pernicioso que há anos se instala no coração de nossa Cidade”, uma livraria frequentada "por elementos reconhecidamente vermelhos residentes nesta Capital, que ali faziam o seu ponto de reunião", em especial funcionários públicos federais, advogados, estudantes e "inúmeros pelegos pagos para propagandearem os ideais marxistas-leninistas em nossa Capital, numa afronta aos brios democráticos de nossa gente" (MARTINS, 1988, p. 138).

Anos 90, Porto Alegre, v. 25, n. 48, p. 299-326, dez. 2018 


\section{Figura 3 - Reprodução da primeira página do jornal A Gazeta, de 5/4/1964}

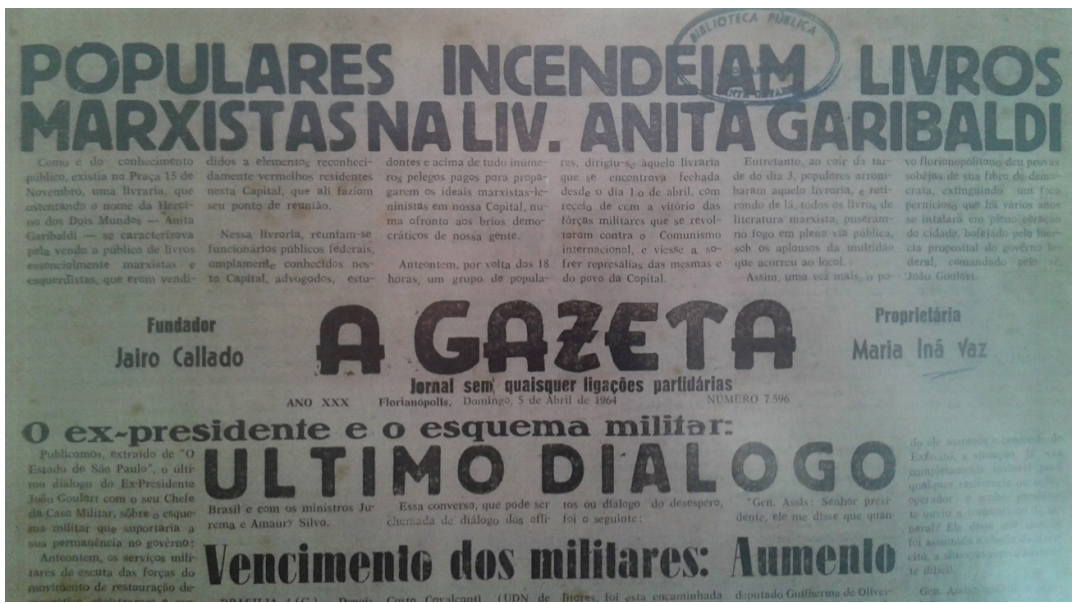

Fonte: Acervo da Biblioteca Pública de Santa Catarina.

$\mathrm{Na}$ prisão, Salim recebeu a notícia da fogueira de livros dois ou três dias após o ocorrido:

No alojamento, através de canais invisíveis, boatos de toda ordem pululam. Embora vagos e inconsistentes, é por eles que se vai saber do incêndio da livraria. [...] É um novo preso que confirma a notícia. E acrescenta: teu nome era repetido, gritado, xingado pelos cabeças do movimento incendiário. [...] Incrédulo te questionas, interrogas teus companheiros, será mesmo por tal motivo que a fogueira foi erguida? Não, impossível? Teu nome é mera desculpa [...]. Constatas: ser ou não ser tua era para eles fator de somenos importância, mero detalhe. [...] O incêndio estava decidido, programado, consciente ou inconscientemente, fazia parte de um esquema. Era uma estratégia a mais, no sentido de mostrar que não estavam para brincadeira, iam levar tudo adiante a ferro e fogo. [...] Como reagirias se lá estivesses? Não tens certeza. Ou não queres tê-la. Ouvir teu nome berrado, ver livros serem atirados às chamas. $\mathrm{O}$ que 
apavora é o ato de vandalismo que se consuma, é a queima, quaisquer que fossem os donos, quaisquer que fossem os livros. [...] Poemas de Cruz e Sousa, Satiricon de Petrônio, compêndio de economia de Caio Prado Junior, Correspondance - supplement de Flaubert, Minhas universidades de Máximo Gorki, Retour de la URSS de André Gide, O Livro dos Médiuns de Allan Kardec, Alcorão, Cine Francês de Manuel Villegas Lopez, Pintura quase sempre de Sérgio Millet, e tantos outros subversivíssimos. [...] Ali se estava cometendo um crime contra a liberdade de expressão, de circulação de ideias, um crime contra a cultura, um crime contra o direito do cidadão escolher o que deseja ler ou o que quer pensar e de que maneira lhe agrada agir, atuar, indo seu direito de liberdade até a liberdade do outro (MIGUEL, 1994, p. 26-27).

Eglê Malheiros também deixou o registro de suas impressões sobre os acontecimentos:

A polícia ficou por perto, impedindo quem não estava participando de se aproximar. [...] Eu vi livros reduzidos a cinza ali. Soube à noite, pois naquela época ninguém tinha telefone. Saí para ir ao Palácio, para saber se tinha alguma notícia sobre o Salim, alguma informação. Fui de ônibus, o ônibus parava ali na Praça Fernando Machado (nós morávamos na Agronômica). Então eu vi aquela barbaridade, a porta arrombada. Perguntei para alguém o que era, o que tinha acontecido, e fui até o Palácio falar com o Fúlvio Vieira. Naquele momento chegou também o Padre Braun, do Colégio Catarinense, que não sabia quem eu era. Foi então que ele disse: "Meu Deus, será que vamos voltar ao tempo do Hitler?” (MIGUEL; MALHEIROS, 2002, p. 61-62).

Ao sair da prisão, Salim procurou informações sobre o ocorrido e teria tomado conhecimento de que além de queimarem a maior parte do estoque de livros, durante o arrombamento da livraria alguns dicionários, enciclopédias, obras de arte, luxuosos 
Entre chamas e labaredas: histórias de fogueiras de impressos...

álbuns de artistas plásticos com reproduções em cores, discos e cópias de filmes foram saqueados, bem como teria desaparecido o dinheiro que se encontrava no caixa do estabelecimento. Em meio ao caos do ataque, foi relatado um episódio de que um livro sobre a história do cubismo teria sido empunhado como perigoso, aos berros de que se trataria de uma obra sobre a Cuba de Fidel Castro (MIGUEL, 1994, p. 22).

Embora Salim Miguel tenha tomado conhecimento da identidade de alguns daqueles que comandaram o ataque à livraria, em textos e entrevistas o autor fazia questão de não citar os seus nomes, por achar que eles não mereciam ser lembrados. $\mathrm{O}$ historiador Valmir Martins foi o primeiro a apontar alguns dos responsáveis pelas ações daquele dia, que teriam agido sob a influência do Instituto Brasileiro de Ação Democrática (IBAD): pessoas ligadas ao Círculo Operário de Florianópolis, entidade relacionada com a igreja católica, e políticos ligados ao Partido Democrata Cristão (MARTINS, 1988, p. 136).

Em Santa Catarina, a ditadura se sustentou pela cooperação e parceria de um "consórcio governamental-empresarial” (LOHN, 2014, p. 18), que envolveu tanto as forças militares e os partidos políticos, em especial PSD e UDN, quanto setores da sociedade civil, como órgãos da imprensa, a cúria metropolitana e entidades como o Instituto de Pesquisas e Estudos Sociais (IPES) e o Instituto Brasileiro de Ação Democrática (IBAD), apoiados pela Embaixada dos Estados Unidos. Todos esses setores se mobilizaram contra uma pretensa ameaça comunista e o apoio que a militância de esquerda, intelectuais e artistas representavam em favor das medidas reformistas defendidas por Jango no Congresso Nacional. Essa articulação de setores reacionários com grupos paramilitares também promoveu cursos de liderança sindical, a fim de enfrentar o que eles consideravam uma ameaça comunista. O Círculo Operário, que em Florianópolis tomou parte do ataque à Livraria Anita Garibaldi, tinha entre as suas lideranças estaduais o Pe. Hélio Simas e o seu irmão, Oswaldo Simas, ambos de Criciúma, cidade carbonífera em que Fernando Pereira Cristino, como agente do PCB, havia contribuído na organização de greves operárias. Essas lideranças mantiveram constante diálogo com o Círculo Operário 
de Florianópolis, a fim de contribuir para a sua organização e fortalecer a ideia da necessidade do golpe civil-militar e do combate ao comunismo (MARTINS, 1988, p. 136).

Segundo Valmir Martins, que analisou uma entrevista de José Carlos Martins, testemunha da fogueira de livros, o ataque à livraria não foi obra do acaso ou de um momento de frenesi entre populares, mas um caso premeditado, organizado com antecedência, onde a queima de livros seria o clímax de uma manifestação que buscava consagrar a vitória dos grupos políticos conservadores sobre aqueles considerados subversivos e indesejados (MARTINS, 1988, p. 139).

A fogueira de livros, defendida pela imprensa como expressão dos "brios democráticos" de parte da população, parece assumir o simbolismo da incineração do contraditório, da eliminação da consciência crítica, da supressão da alteridade e das aspirações realmente democráticas, como a consciência de que viver em sociedade exige negociações permanentes entre os mais variados atores sociais e as suas diferenças de pensamento. Escorados por parcela significativa da opinião pública e nas Forças Armadas, os promotores da nova ordem política premeditaram uma fogueira para expressar a pretensão de não abrirem mão de seus valores conservadores, apoiados numa ética cristã peculiar. Restou, assim, a pergunta que Salim Miguel se fez ao ser informado sobre a fogueira: "Será mesmo que os infelizes acreditavam que a força do fogo seria suficiente para extirpar a força das ideias?” (MIGUEL, 1994, p. 28).

\section{Marcos flamejantes na história do livro e da leitura}

Os três casos aqui relatados ficaram marcados por características distintas, de fundo nacionalista, religioso e político. $\mathrm{O}$ episódio do Club Germânia pareceu ser uma ocorrência de fogueira com livros e não tanto propriamente uma fogueira de livros. Os impressos foram apenas mais um dos objetos encontrados no interior da instituição e que foram arremessados ao fogo, tal como as cortinas, o piano, as cadeiras, e como teria sido a própria edificação do clube, salva nos últimos instantes. Os livros da biblioteca, embora sejam objetos carregados de simbolismo, foram queimados por suas 
características físicas próprias para a combustão e arderam no fogo por comporem um cenário geral em que arderia tudo o que estivesse associado ao elemento germânico. Ironicamente, onde ardeu a primeira fogueira com livros da cidade funciona, atualmente, a Biblioteca Pública do Estado de Santa Catarina, numa coincidência que parece clamar que, ao fim, o livro sempre vence.

O caso do Club Germânia difere da fogueira de quadrinhos produzida pelos alunos do Colégio Catarinense, onde o impresso em si e o seu conteúdo foram o alvo da autocensura dos alunos, que o consideraram uma leitura perniciosa, justamente numa época em que essas publicações passavam por seu primeiro grande momento editorial no país, atingindo tiragens recordes na mesma proporção em que aumentavam os discursos conservadores, sobretudo nos círculos religiosos. No caso do Colégio Catarinense, a fogueira foi uma operação de "higiene social” (LYONS; LEAHY, 1999, p. 22), preparada para exterminar o que poderia ser um foco de infecção intelectual que estaria atingindo o corpo discente da instituição Os impressos eram a materialização de valores não comungados e vistos como alienantes, imorais, contraproducentes, e cuja leitura era proibida por comportar espaços e proposições irreligiosas, políticas, nacionalistas e obscenas (VILLALTA, 2009, p. 251). No simbolismo cristão, o fogo é o elemento purificador que reestabelece a ordem e elimina tudo o que é nocivo. A queima na fogueira, que remete tanto aos homens da Igreja medieval quanto aos inquisidores do Santo Ofício, assemelha-se a uma prática de eliminação pública do Mal (CARNEIRO, 2002, p. 27-28), num cenário maniqueísta que se julgava capaz de discernir o que seriam as boas e as más leituras.

Percebe-se também, por parte da "imprensa pedagógica" em circulação no interior do colégio, uma tentativa de "saneamento" das leituras ao se identificar formas de normatização e de desenvolvimento de uma postura de vigilância em relação aos livros e às revistas que poderiam influenciar a formação moral da comunidade discente, o que dialoga com o contexto em voga na década de 1950, com ações que buscavam estabelecer dispositivos de controle da leitura, especialmente da literatura infanto-juvenil, coibindo e interditando o acesso a determinados impressos, como foi o caso, no Rio Grande do Sul, de uma série de proposições de projetos 
de lei e campanhas (VENTORINI, 2009), que culminaram com a criação de uma Comissão Especial de Estudo e Classificação de Publicações Periódicas, do Centro de Pesquisas e Orientações Educacionais, subordinada à Secretaria de Educação e Cultura daquele Estado (PERES; VAHL, 2005).

O órgão oficial dos alunos do Colégio Catarinense - O Colegial - estabeleceu discursivamente o desejo de controle da leitura, justificando e autorizando atos como uma fogueira de dois metros de impressos interditados, julgados impróprios de circularem. Essa visão de mundo católica, que ainda comungava de um Index Librorum Prohibitorum, supunha a supremacia do texto sobre a produção de sentidos dos leitores. Um discente "em formação" seria um leitor "moldável", submisso aos mecanismos textuais, portanto, pronto a receber um conteúdo preestabelecido. A leitura livre era uma prática potencialmente perigosa que poderia levar o leitor a caminhos não desejados.

A sobrevivência das histórias em quadrinhos, atestada pela sua contínua circulação nos pontos de venda da cidade e nos relatos memorialísticos de seus leitores, demonstra que a arbitrariedade da repreensão, mesmo quando se atribuía a ela uma função protetora, ignora que a circulação dos impressos é sempre mais fluida do que certamente desejam os seus censores, sobretudo quando se trata de obras proibidas ou desaconselháveis, capazes de aguçar ainda mais os sentidos dos leitores por elas atraídos. A leitura é uma prática incontrolada que se dissemina conduzindo os leitores a encontrar outras leituras (CHARTIER, 1998, p. 104), especialmente dentro de um mercado editorial em expansão, de fácil acesso e de preços progressivamente mais baratos como aqueles praticados no comércio das revistas em quadrinhos.

Por fim, a fogueira dos livros da Livraria Anita Garibaldi demonstra um fluxo de paixões políticas e religiosas que foram concentradas num revanchismo que buscou atacar tanto os seus proprietários e frequentadores quanto a memória histórica que seus livros representavam. Foi um ritual público elaborado de forma premeditada, com vistas à consagração de uma obtusa intolerância, que decidiu perseguir e eliminar toda a expressão de ideias que não fossem aquelas que o grupo opressor comungava. Os livros foram 
queimados em nome do anticomunismo, da fé e da democracia, argumentos costumeiramente utilizados para se justificar e provocar as intervenções autoritárias mais significativas ocorridas no período republicano da história brasileira (MOTTA, 2000, p. 13).

$\mathrm{O}$ anticomunismo é um fenômeno complexo que, embora não possa ser caracterizado como restrito a um grupo específico (intelectuais, militares, Igreja Católica, imprensa etc.), é caracterizado por práticas cujo fim é impedir a expansão e denegrir a imagem das ideologias de esquerda (RODEGHERO, 2003), utilizando de recursos diversos para cumprir com o seu objetivo. Em Florianópolis, o fenômeno do anticomunismo se uniu às disputas intelectuais provincianas para queimar livros respaldando-se no interesse da defesa de valores em voga nas discussões políticas do contexto nacional, reproduzidas nas tensões locais. Nos dias que antecederam o golpe militar, estudantes manifestavam-se no Centro de Florianópolis em defesa das reformas de base do presidente João Goulart e contra o aumento das passagens de ônibus definido pela prefeitura, enquanto a primeira-dama Edith Ramos, mulher do governador Celso Ramos, fazia a convocação para a versão local da Marcha da Família com Deus pela Liberdade, que reuniu centenas de pessoas em frente à catedral metropolitana, na mesma Praça XV de Novembro que, dias depois, viu arderem os livros da Livraria Anita Garibaldi.

O caso ocorrido em Florianópolis se relaciona com outros exemplos de intolerância contra intelectuais, livrarias e livros associados ao comunismo acontecidos no Brasil do século XX, como, por exemplo, a fogueira de livros ocorrida em Salvador, em 1937, que incinerou centenas de exemplares de autores como Jorge Amado e José Lins do Rego; ou, as diligências feitas pela polícia carioca, também em 1937, em diversas livrarias do Rio de Janeiro, apreendendo títulos considerados nocivos e mesmo histórias em quadrinhos de Tarzan, de Edgar Rice Burroughs. A bibliografia assimilada pela esquerda brasileira foi a mais visada pelos setores conservadores e pelos órgãos de repressão do Estado brasileiro, tanto no Estado Novo quanto no regime militar. Como observou Maria Luiza Tucci Carneiro, "o 'credo vermelho' transformou-se na nova heresia do século XX” (CARNEIRO, 2002, p. 109). 
Os casos aqui apresentados convergem quando desnudam a intolerância reacionária presente na cultura de destruição de impressos e nos embates entre o conservadorismo e a liberdade intelectual. As fogueiras são marcos flamejantes na história do livro e da leitura, a fazer recordar o que escreveu Chartier, na continuidade da epígrafe que abre este artigo: "a cultura escrita é inseparável dos gestos violentos que a reprimem" (CHARTIER, 1999, p. 23). Revolver, pela escrita, esses acontecimentos permite reconhecer rastros de um passado que ainda assombra o presente e, quiçá, o futuro, e, desse modo, potencializa a necessidade de apresentá-los mais uma vez. É a narrativa, segundo Ricoeur, "[...] que torna acessível a experiência humana do tempo" (2010, p. XI), e é a ela que recorremos para evitar possibilidades de outras fogueiras que tenham como combustível o livro, entre chamas e labaredas. Afinal, ter ou frequentar uma livraria, portar e ler um livro continuam sendo, em tempos sombrios, alguns dos gestos mais anárquicos e provocativos que se pode ter.

\section{BETWEEN FIRE AND FLAME: STORIES OF PRINTED BURNING IN FLORIANOPOLIS IN THE 20TH CENTURY}

Abstract: This article discusses the destruction of printed, made through the public burning, held in three different times (1917, 1950 and 1964) in Florianopolis, Santa Catarina, especially. the destruction of books from the bookstore Anita Garibaldi which had belonged to the writer Salim Miguel, in 1964, for evidence a public ritual, violent and persecutory, organized by men who decided to eliminate any expression of ideas contrary to their interests. The similarities and disparities of the three cases here recorded, documented through newspapers, magazines and memorialistic reports, emphasize the role and place of the print in contemporary societies as well as highlight the so-called biblioclasts, with such events converging to know intolerance reactionary presence in the culture of book destruction and in the clashes between sectarianism and intellectual freedom in the 20th century.

Keywords: Printed burning. Salim Miguel. Banned books. Intellectual freedom. 
Entre chamas e labaredas: histórias de fogueiras de impressos...

\section{Referências}

BÁEZ, Fernando. História universal da destruição dos livros: das tábuas sumérias à guerra do Iraque. Rio de Janeiro: Ediouro, 2006.

CARDOZO, Flávio José (Org.). Salim na claridade. Florianópolis: FCC Edições, 2001.

CARNEIRO, Maria Luiza Tucci. Livros proibidos, ideias malditas. São Paulo: Ateliê Editorial, 2002.

CHARTIER, Roger. A aventura do livro: do leitor ao navegador. São Paulo: UNESP, 1998.

CHEREM, Rosângela Miranda et al. Ensaios sobre Santa Catarina. Florianópolis: Letras Contemporâneas, 2000.

CPDOC. Verbete Nereu Ramos. Disponível em: <http://cpdoc.fgv.br/sites/ default/files/verbetes/primeira-republica/RAMOS,\%20Nereu.pdf $>$. Acesso em: 2 ago. 2016.

CUNHA, Maria Teresa Santos. Do erotismo à pornografia: pílulas de comportamento nos livros de bolso de Corin Tellado e Carlos Zéfiro. In: BRAGANÇA, Aníbal; ABREU, Márcia (Org.). Impresso no Brasil: Dois séculos de livros brasileiros. São Paulo: Editora UNESP, 2010.

CUNHA, Maria Teresa Santos. Armadilhas da sedução. Os romances de M. Delly. Belo Horizonte: Editora Autêntica, 1999.

FALCÃO, Luís Felipe. A Guerra Interna (Integralismo, Nazismo e Nacionalização). In: BRANCHER, Ana Lice (Org.). História de Santa Catarina: Estudos Contemporâneos. Florianópolis: Letras Contemporâneas, 2000.

FÁVERI, Marlene de. Memórias de uma (outra) guerra: cotidiano e medo durante a Segunda Guerra em Santa Catarina. Itajaí: Univali; Florianópolis: EdUFSC, 2004.

GERTZ, Rene. O perigo alemão. Porto Alegre: Ed. Universidade/UFRGS, 1998. GONÇALO JUNIOR. A guerra dos gibis: a formação do mercado editorial brasileiro e a censura aos quadrinhos, 1933-64. São Paulo: Companhia das Letras, 2004.

KLUG, João. Imigração e Luteranismo em Santa Catarina. A comunidade alemã em Desterro, Florianópolis. Florianópolis: Papa-Livro, 1994.

LOHN, Reinaldo Lindolfo. Relações políticas e ditadura: do consórcio autoritário à transição controlada. In: BRANCHER, Ana Lice; LOHN, Reinaldo 
Lindolfo (Org.). Histórias na Ditadura: Santa Catarina (1964-1985). Florianópolis: EdUFSC, 2014.

LYONS, Martyn; LEAHY, Cyana. A palavra impressa: histórias da leitura no século XIX. Rio de Janeiro: Casa da Palavra, 1999.

MARTINS, Valmir. O golpe de 64: a participação do grupo civil em Florianópolis. In: DIAS, José de Souza (Org.). Santa Catarina em perspectiva: os anos do Golpe. Petrópolis: Vozes, 1988.

MATOS, Felipe. Uma Ilha de Leitura: notas para uma história de Florianópolis através de suas livrarias, livreiros e livros. Florianópolis: EdUFSC, 2008a.

. Sob os auspícios da Livraria Rosa: Redutos literários e circulação de cultura letrada em Florianópolis. Dissertação (Mestrado em História)-Universidade Federal de Santa Catarina, Florianópolis, 2008b.

MATOS, Felipe. Camadas de sentidos, memórias instituídas: considerações sobre o cânone modernista catarinense. In: FLORES, Maria Bernardete Ramos; PETERLE, Patrícia (Org.). História e Arte: herança, memória, patrimônio. 1. ed. São Paulo: Rafael Copetti Editor, 2014.

MIGUEL, Salim. Primeiro de Abril. Narrativas da cadeia. Rio de Janeiro: José Olympio; São Carlos: EdUFScar, 1994.

MIGUEL, Salim; MALHEIROS, Eglê. Memória de Editor. Florianópolis: Escritório do Livro, 2002.

MOTTA, Rodrigo Patto Sá. Em guarda contra o perigo vermelho: o anticomunismo no Brasil (1917-1964). Tese de Doutorado (História)-Universidade de São Paulo, São Paulo, 2000.

PERES, Eliane Peres; VAHL, Monica Maciel. Saneamento da literatura infantojuvenil: o esforço do CPOE e da Revista do Ensino (RS). Oficina do Historiador, Porto Alegre, v. 8, n. 2, p. 137-153, jul./dez. 2005.

RICOEUR, Paul. Tempo e Narrativa. A intriga e a narrativa histórica. São Paulo: Editora WMF; Martins Fontes, 2010.

RODEGHERO, Carla Simone. O diabo é vermelho: imaginário anticomunista e a Igreja Católica no Rio Grande do Sul (1945-1964). Passo Fundo: UPF, 2003.

SANTOS, Márcia Regina dos. Formação em páginas marcadas: sugestões de leituras feitas aos alunos do Colégio Catarinense (1945-1950). Trabalho de Conclusão de Curso (Bacharelado em História)-Centro de Ciências Humanas e da Educação, Florianópolis, 2003. 
Entre chamas e labaredas: histórias de fogueiras de impressos...

VENTORINI, Eliana. Regulação da leitura e da literatura infanto-juvenil no Rio Grande do Sul na década de 1950: interdição, triagem e intervenção das autoridades. Dissertação (Mestrado em Educação)-UFRGS, Porto Alegre, 2009. VILLALTA, Luiz Carlos. Os livreiros, os "livros proibidos" e as livrarias em Portugal sob o olhar do Antigo Regime (1793-1807). In: NEVES, Lúcia Maria Bastos (Org.). Livros e impressos: retratos dos setecentos e Oitocentos. Rio de Janeiro: EDUERJ, 2009.

WERLE, Bibiana. Entre o riso e a dor: setenta anos após 1945. Fronteiras: Revista Catarinense de História, Florianópolis, n. 26, 2015.

Recebido em: 19/01/2018

Aprovado em: 20/06/2018 